\section{Establishment and Performance of Bluegrass Species and Tall Fescue under Reduced-input Maintenance in a Temperate Mediterranean Environment}

\author{
Stefano Fiorio ${ }^{1}$, Stefano Macolino ${ }^{1,3}$, and Bernd Leinauer ${ }^{2}$
}

ADDITIONAL INDEX WORDs. seeding time, drought, hybrid bluegrass, turf quality, NDVI

SUMMARY. Turfgrass water conservation has become important in many parts of the world, including the transition zones of Mediterranean Europe. Species selection is considered one of the most important factors influencing turfgrass water use, and drought-tolerant cool-season species are encouraged to be used in areas where long dormancy periods of warm-season grasses is unacceptable. A field study was conducted from Mar. 2007 to Sept. 2009 at Padova University, Italy, to evaluate establishment and performance of nine turfgrass cultivars under reduced-input maintenance. The study included hybrid bluegrass (Poa pratensis $\times$ P. arachnifera) cultivars Solar Green, Thermal Blue, and Thermal Blue Blaze; kentucky bluegrass (Poa pratensis) cultivars Cocktail, Cynthia, and Geronimo; and tall fescue (Festuca arundinacea) cultivars Apache, Murray, and Regiment. Establishment rate was assessed after two seeding dates (20 Mar. and 20 Sept.), and grasses were subsequently fertilized with $15 \mathrm{~g} \cdot \mathrm{m}^{-2}$ nitrogen per year and irrigated once every 2 weeks at $40 \%$ of reference evapotranspiration from June to August. Turfgrass and weed cover were estimated 60 days after seeding (DAS), and turf quality was evaluated weekly on a scale of 1 (worst) to 9 (best). Normalized difference vegetation index (NDVI) was measured weekly during 2009. Tall fescue cultivars exhibited greater quality than hybrid bluegrass or kentucky bluegrass, under both spring and autumn seeding. Hybrid bluegrass had similar quality to kentucky bluegrass cultivars, although they performed well only when sown in autumn. Our results suggest that among the tested grasses, tall fescue performed better under the reduced irrigation in a Mediterranean transition zone climate than kentucky bluegrass or hybrid bluegrass.

A $s$ water availability for turfgrass irrigation has become increasingly limited, improving water conservation has become an important objective in turfgrass management. Most research focused on turfgrass water use has been conducted in arid regions of the United States (Kenna, 2008), and little consideration has been given to water conservation in more temperate climates. There are several factors that affect water consumption in turf; however, species selection is considered the most important (Christians, 1998; Huang and

This research was funded by the University of Padua (MIUR ex 60\%).

Dr. Rossana Sallenave's assistance with the manuscript is gratefully acknowledged.

${ }^{1}$ Department of Agronomy Food Natural Resources Animals and Environment, University of Padova, Agripolis, Viale dell'Università 16, 35020 Legnaro, Padova, Italy

${ }^{2}$ Department of Extension Plant Sciences, New Mexico State University, N230 Skeen Hall, Las Cruces, NM 88003

${ }^{3}$ Corresponding author. E-mail: stefano.macolino@ unipd.it.
Fry, 1999). In transition zone environments neither cool- nor warm-season grasses grow well all year around. Warm-season grasses perform well in the summer while cool-season grasses perform well during the cooler months (Jiang and Huang, 2000; Richardson et al., 2008). Cool-season grasses are susceptible to heat and drought stresses and have high water requirements in the summer; whereas warmseason grasses go dormant in the autumn and turn brown after the first hard frost (Beard, 1973). The Venetian Valley in Italy is a transition zone with a humid subtropical climate in the summer. In this region, cool-season grasses are generally preferred over warm-season grasses, presumably because of the winter dormancy period of warm-season grasses, which results in a prolonged loss of turfgrass color for up to five months (Macolino et al., 2010).

Only a few cool-season species can be used in transition zones without large inputs of water during the summer. The development of coolseason grasses with improved drought tolerance is one of the main objectives of the turf industry, particularly in light of the increasing scrutiny of water consumption for landscape irrigation (Su et al., 2007). Tall fescue is widely used in transition zones and is generally considered one of the most droughttolerant cool-season species (Brede, 2000; Cereti, 2002). This species forms a deep root system, which provides resistance to drought (Sheffer et al., 1987). However, it does not tolerate low mowing heights and has poor recuperative abilities once injured (Beard, 1973; Croce et al., 2006). Furthermore, the wide leaf blades result in lower quality turf, making tall fescue unpopular with some turf managers and users (Miele et al., 2002).

Kentucky bluegrass is one of the most popular species in Mediterranean regions for turf purposes. It is a rhizomatous grass that easily established when mixed with bunch-type species such as perennial ryegrass (Lolium perenne) and tall fescue. One of the disadvantages of this species is that during periods of severe heat and drought it goes dormant and loses its green color (Fry and Huang, 2004; Suplick-Ploense and Qian, 2005). Kentucky bluegrass has been hybridized with a number of other species in an effort to improve its adaptability and performance under drought conditions and to decrease its irrigation requirements. Hybrid bluegrass, genetic crosses between kentucky bluegrass and texas bluegrass (Poa arachnifera), has been reported by some authors to be more drought and heat tolerant

\begin{tabular}{llll}
\hline $\begin{array}{l}\text { Units } \\
\begin{array}{l}\text { To convert U.S. to SI, } \\
\text { multiply by }\end{array}\end{array}$ & U.S. unit & SI unit & $\begin{array}{l}\text { To convert SI to U.S., } \\
\text { multiply by }\end{array}$ \\
\hline 0.3048 & $\mathrm{ft}$ & $\mathrm{m}$ & 3.2808 \\
0.0929 & $\mathrm{ft}^{2}$ & $\mathrm{~m}^{2}$ & 10.7639 \\
33.9057 & $\mathrm{oz} / \mathrm{yard}^{2}$ & $\mathrm{~g} \cdot \mathrm{m}^{-2}$ & 0.0295 \\
1 & $\mathrm{ppm}$ & $\mathrm{mg}^{-1} \mathrm{~kg}^{-1}$ & 1 \\
$\left({ }^{\circ} \mathrm{F}-32\right) \div 1.8$ & ${ }^{\circ} \mathrm{F}$ & ${ }^{\circ} \mathrm{C}$ & $\left({ }^{\circ} \mathrm{C} \times 1.8\right)+32$
\end{tabular}


Table 1. Monthly average air temperatures and precipitations, including long-term averages (1963-2007), wind speed at a height of $10 \mathrm{~m}(32.8 \mathrm{ft})$, soil temperatures at a depth of $100 \mathrm{~mm}\left(3.94\right.$ inches), and reference evapotranspiration $\left(\mathrm{ET}_{\mathrm{o}}\right)$ from Jan. 2007 to Dec. 2009 at the experimental farm of Padova University in Legnaro, Italy.

\begin{tabular}{|c|c|c|c|c|c|c|c|c|c|c|c|c|}
\hline$\underline{Y r}$ & Jan. & Feb. & Mar. & Apr. & May & June & July & Aug. & Sept. & Oct. & Nov. & Dec. \\
\hline \multicolumn{13}{|c|}{ Air temp $\left({ }^{\circ} C\right)^{z}$} \\
\hline 2007 & 5.7 & 6.9 & 10.4 & 16.1 & 19.1 & 22.1 & 23.7 & 21.9 & 17.4 & 13.1 & 7.5 & 3.2 \\
\hline 2008 & 4.7 & 4.9 & 8.2 & 12.5 & 18.0 & 21.1 & 23.3 & 23.4 & 18.0 & 14.6 & 8.8 & 4.7 \\
\hline 2009 & 2.9 & 5.2 & 9.0 & 14.3 & 20.2 & 21.6 & 24.2 & 25.5 & 20.8 & 14.3 & 10.1 & 6.9 \\
\hline 45-year avg & 2.0 & 4.1 & 7.8 & 11.6 & 16.6 & 20.2 & 22.3 & 21.9 & 18.2 & 13.1 & 7.2 & 2.9 \\
\hline 2008 & 31 & 32 & 51 & 108 & 93 & 80 & 58 & 78 & 60 & 46 & 151 & 133 \\
\hline 2009 & 57 & 57 & 105 & 126 & 26 & 87 & 79 & 21 & 190 & 44 & 92 & 54 \\
\hline 45-year avg & 53 & 49 & 56 & 69 & 74 & 82 & 74 & 76 & 72 & 80 & 76 & 60 \\
\hline \multicolumn{13}{|c|}{ Wind speed $\left(m \cdot s^{-1}\right)^{z}$} \\
\hline 2007 & 1.5 & 1.5 & 2.6 & 2.1 & 2.3 & 2.2 & 2.2 & 2.0 & 2.2 & 2.2 & 1.9 & 1.6 \\
\hline \multicolumn{13}{|c|}{ Soil temp $\left({ }^{\circ} \mathrm{C}\right)^{z}$} \\
\hline 2007 & 6.0 & 7.1 & 9.9 & 14.9 & 19.2 & 21.3 & 24.4 & 23.3 & 18.7 & 13.9 & 7.8 & 4.0 \\
\hline 2008 & 4.7 & 5.2 & 8.6 & 12.1 & 17.4 & 21.4 & 24.6 & 24.3 & 19.8 & 15.3 & 10.3 & 5.7 \\
\hline 2009 & 3.5 & 5.4 & 8.7 & 14.1 & 19.9 & 22.7 & 24.5 & 25.3 & 0.9 & 5.9 & 10.4 & 8.0 \\
\hline \multicolumn{13}{|c|}{$E T_{o}(m m)^{z}$} \\
\hline 2007 & 11 & 21 & 58 & 104 & 122 & 130 & 162 & 118 & 83 & 47 & 25 & 13 \\
\hline 2008 & 12 & 23 & 49 & 69 & 113 & 125 & 149 & 134 & 81 & 47 & 20 & 14 \\
\hline 2009 & 16 & 28 & 55 & 78 & 136 & 142 & 162 & 151 & 68 & 39 & 16 & 13 \\
\hline
\end{tabular}

${ }^{\mathrm{z}}\left(1.8 \times{ }^{\circ} \mathrm{C}\right)+32={ }^{\circ} \mathrm{F}, 1 \mathrm{~mm}=0.0394$ inch, $1 \mathrm{~m} \cdot \mathrm{s}^{-1}=2.2369 \mathrm{mph}$.

than most of the other cool-season grasses including kentucky bluegrass (Read et al., 1999) and may be able to withstand higher temperatures and extended drought without going dormant (Abraham et al., 2004; Read et al., 1994). Comparisons in drought tolerance and water use efficiency among kentucky bluegrass cultivars and experimental hybrids have been recently documented (Su et al., 2007, 2008). Read et al. (1999) reported that hybrid bluegrass showed similar visual qualities to kentucky bluegrass when used in home-lawns and on golf courses. However, there is considerable debate regarding the claims of greater heat and drought tolerance of hybrid bluegrass. Richardson et al. (2009) reported that some improved drought-tolerant cultivars of kentucky bluegrass performed better than many hybrid bluegrasses in a cooler, coastal climate in the northern United States. The performance of hybrid bluegrass particularly in transition zones has yet to be thoroughly investigated; therefore, their use in these areas is limited.

Turfgrass quality is evaluated by integrating factors of canopy density,

Table 2. Results of analysis of variance testing the effects of seeding time [( spring seeding (23 Mar. 2007) and autumn seeding (20 Sept. 2007)], sampling season, and their interactions on green cover ( $60 \mathrm{~d}$ after seeding), weed cover ( $60 \mathrm{~d}$ after seeding), visual quality (1-9 scale), and normalized difference vegetation index (NDVI) of nine turfgrass cultivars (Apache, Regiment, and Murray tall fescue; Cynthia, Cocktail, and Geronimo kentucky bluegrass; Solar Green, Thermal Blue, and Thermal Blue Blaze hybrid bluegrass).

\begin{tabular}{lcccc}
\hline Effect & Green cover & Weed cover & Visual quality & NDVI \\
\hline Cultivar $(\mathrm{CV})$ & ${ }^{* * *} \mathrm{z}$ & $* * *$ & ${ }^{* * *}$ & ${ }^{* * *}$ \\
Seeding time $(\mathrm{ST})$ & ${ }^{* * *}$ & ${ }^{* *}$ & ${ }^{* * *}$ & $\mathrm{NS}$ \\
$\mathrm{CV} \times \mathrm{ST}$ & $\mathrm{NS}^{\mathrm{z}}$ & $\mathrm{NS}$ & ${ }^{* * *}$ & $\mathrm{NS}$ \\
Season $(\mathrm{S})^{\mathrm{y}}$ & & & ${ }^{* * *}$ & $* * *$ \\
$\mathrm{CV} \times \mathrm{S}$ & & $* * *$ & $\mathrm{NS}$ \\
$\mathrm{ST} \times \mathrm{S}$ & & & $\mathrm{NS}$ & $\mathrm{NS}$ \\
$\mathrm{CV} \times \mathrm{ST} \times \mathrm{S}$ & & &
\end{tabular}

$\mathrm{z}^{* * *}$ Significant $\mathrm{F}$ test at $P \leq 0.001, \mathrm{NS}=$ not significant at $P \leq 0.05$.

y Season for visual quality indicates weekly ratings that were averaged every three months (January to March, April to June, July to September, and October to December) and analyzed as winter, spring, summer, and autumn from Oct. 2007 to Sept. 2009 for a total of eight seasons. Season for NDVI indicates weekly measurements during 2009 that were averaged every three months (January to March, April to June, and July to September) and analyzed as winter, spring, and summer.

leaf texture, uniformity, color, growth habit, and smoothness (Turgeon, 1991). A visual evaluation on a numeric scale of 1 to 9 is the most widespread method for evaluating turfgrass quality (Bunderson et al., 2009). Some researchers have demonstrated that visual ratings may vary significantly among evaluators or even for the same evaluator over time, and that such ratings tend to be inaccurate and nonreproducible (Bell et al., 2002; Horst et al., 1984). Multispectral radiometry and vegetation indices such as NDVI, which measure spectral reflectance of the turf canopy at the wavelengths of 
red and near-infrared, provide quantitative and objective evaluations of turfgrass quality response to various stresses (Bell et al., 2000, 2002; Schuerger et al., 2003). By using multispectral radiometry, Trenholm et al. (1999) reported significant correlations between spectral reflectance and visual quality in seashore paspalum (Paspalum vaginatum) ecotypes and hybrid bermudagrass (Cynodon dactylon $\times$ C. transvaalensis) cultivars. Recently, Lee et al. (2011) demonstrated that the NDVI values in kentucky bluegrass and hybrid bluegrass were influenced by mowing height and recommended that plots be maintained with the same species and at the same mowing height to reduce variability when using NDVI to evaluate turfgrass quality.

Spring seeding establishment in transition zones is generally difficult for cool-season species and especially for kentucky bluegrass because germination and the subsequent establishment occur more slowly than in many other cool-season turfgrasses (Huff, 2003). If seed is not planted at the correct time, summer heat can delay seedling growth and stand establishment. Because of their reportedly better heat and drought tolerance, hybrid bluegrass may be better suited to spring establishment from seed in these zones than kentucky bluegrass. However, little information is available about optimum times of year for hybrid bluegrass to establish.

Information is also lacking on the speed of establishment and performance of hybrid bluegrass in comparison with kentucky bluegrass and tall fescue in Mediterranean, transition zone climates. The objective of this study was to compare establishment and performance of the three aforementioned cool-season species seeded in autumn and spring. To address concerns surrounding the need to conserve potable water, turfgrass performance was studied under reduced irrigation in a Mediterranean transition zone climate.

\section{Materials and methods}

A field trial was conducted from Mar. 2007 to Sept. 2009 at the experimental farm of Padova University in northern Italy (lat. $45^{\circ} 20^{\prime} \mathrm{N}$, long. $11^{\circ} 57^{\prime} \mathrm{E}$, elevation $8 \mathrm{~m}$ ) to compare rate of establishment and performance of three hybrid bluegrass cultivars to that of three kentucky bluegrass cultivars and three tall fescue cultivars under reduced irrigation. The site is characterized by a subtropical climate with a yearly mean temperature of $12.2^{\circ} \mathrm{C}$ and $824 \mathrm{~mm}$ of rainfall. Monthly average air and soil temperature, precipitation, and reference evapotranspiration $\left(\mathrm{ET}_{\mathrm{o}}\right)$ during the research period are listed in Table 1 . Fifty-four plots deriving from the factorial combination of nine cultivars and two seeding times were established on a silty-loam soil and arranged in a split-plot design with three replicates. The soil at the site had a $\mathrm{pH}$ of $8.3,2.1 \%$ organic matter, a carbon/ nitrogen ratio of 11.4 , an available phosphorous content of $30 \mathrm{mg} \cdot \mathrm{kg}^{-1}$ (Olsen method), and an exchangeable potassium content of $147 \mathrm{mg} \cdot \mathrm{kg}^{-1}$ [buffered barium chloride $\left(\mathrm{BaCl}_{2}\right)$ method]. Main plot size was $8 \mathrm{~m}^{2}$ $(4 \mathrm{~m} \times 2 \mathrm{~m})$ and subplot size measured $4 \mathrm{~m}^{2}(2 \mathrm{~m} \times 2 \mathrm{~m})$. Cultivars represented the main plots and seeding time was assigned to subplots. The nine cultivars included Solar Green, Thermal Blue, and Thermal Blue Blaze hybrid bluegrass; Cocktail, Cynthia, and Geronimo kentucky bluegrass; and Apache, Murray, and Regiment tall fescue. The cultivars represent some of the most popular grasses in the area of study (based on the manufacturer's information).

Plots were seeded on 23 Mar. 2007 (Spring seeding) and 20 Sept. 2007 (Autumn seeding). Seeding rate was based on manufacturers' information on pure live seed (PLS) and consisted of $40 \mathrm{~g} \cdot \mathrm{m}^{-2}$ PLS for tall fescue and $20 \mathrm{~g} \cdot \mathrm{m}^{-2}$ PLS for both kentucky bluegrass and hybrid bluegrass. Before seeding, the soil was fertilized with a complete fertilizer to provide $5 \mathrm{~g} \cdot \mathrm{m}^{-2}$ of nitrogen $(\mathrm{N})$, $6.6 \mathrm{~g} \cdot \mathrm{m}^{-2}$ of phosphorus $(\mathrm{P})$, and $12.4 \mathrm{~g} \cdot \mathrm{m}^{-2}$ of potassium (K). After seeding and fertilizing, plots were hand-raked from different directions to cover the seeds with soil. During the establishment period, daily irrigation in sufficient amounts was applied to the plots to prevent drought stress. Sixty DAS (28 May 2007 for plots seeded in Spring 2007 and 26 Nov. 2007 for plots seeded in Autumn

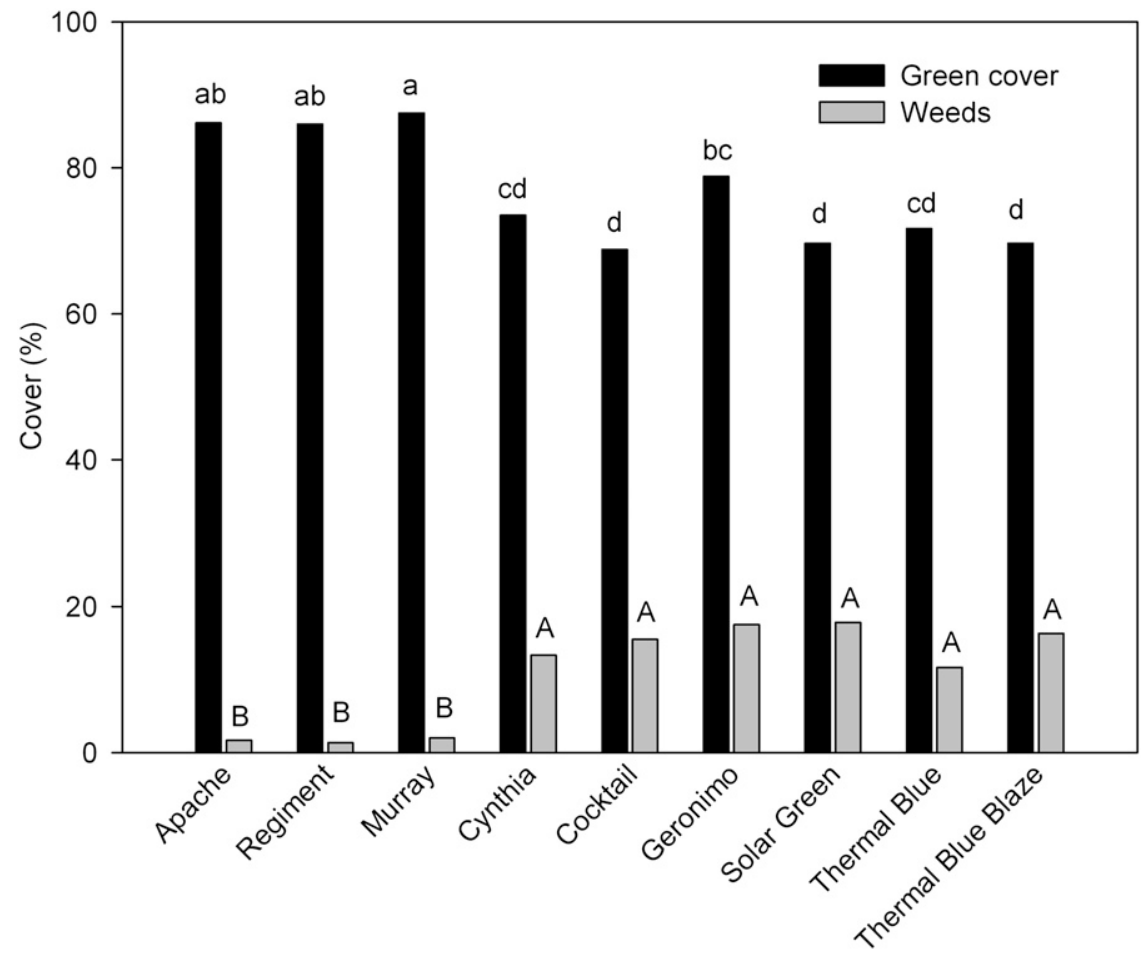

Fig. 1. Percentage green cover (turfgrass + weeds) and weeds percentage at $60 \mathrm{~d}$ after seeding of tall fescue ('Apache', 'Regiment', 'Murray'), kentucky bluegrass ('Cynthia', 'Cocktail', 'Geronimo'), and hybrid bluegrass ('Solar Green', 'Thermal Blue', 'Thermal Blue Blaze') cultivars. Data represent an average of two seeding times [spring (23 Mar. 2007) and autumn (20 Sept. 2007)] and three replicates. Letters denote differences among cultivars via Fisher's protected least significant difference test $(P \leq 0.05)$, uppercase letters for weeds and lowercase letters for green cover. 
2007), coverage of the plots was estimated using visual ratings that described the percentage of the plots covered by plants (turf species and weeds) and the portion of the plots covered by weeds.

Fertilization by means of a slowrelease fertilizer $(15 \mathrm{~N}-3.9 \mathrm{P}-12.5 \mathrm{~K})$ was applied five times during each year of the investigative period. The $\mathrm{N}$ forms in the fertilizer included $2.5 \%$ nitrate- $\mathrm{N}, 7.5 \%$ ammonia- $\mathrm{N}$, and $5 \%$ isobutylidene diurea. Nutrients were provided in March (20 g. $\left.\mathrm{m}^{-2}\right)$, May $\left(13.3 \mathrm{~g} \cdot \mathrm{m}^{-2}\right)$, July $\left(16.7 \mathrm{~g} \cdot \mathrm{m}^{-2}\right)$, September $\left(30 \mathrm{~g} \cdot \mathrm{m}^{-2}\right)$, and December $\left(20 \mathrm{~g} \cdot \mathrm{m}^{-2}\right)$, and amounted to an annual total of $15 \mathrm{~g} \cdot \mathrm{m}^{-2} \mathrm{~N}, 3.9 \mathrm{~g} \cdot \mathrm{m}^{-2} \mathrm{P}$, and $12.5 \mathrm{~g} \cdot \mathrm{m}^{-2} \mathrm{~K}$. Total $\mathrm{N}$ per year represented $\approx 1.5 \mathrm{~g} \cdot \mathrm{m}^{-2} \mathrm{~N}$ per growing month or $30 \%$ of an annually recommended $\mathrm{N}$ fertilization rate for kentucky bluegrass (Beard, 1973; Christians, 1998). The dates of application were 14 May, 16 July, 12 Sept., and 7 Dec. 2007; 14 Mar., 15 May, 14 July, 15 Sept., and 8 Dec. 2008; and 12 Mar., 14 May, 16 July, and 16 Sept. 2009. During the growing seasons, plots were mowed once a week with a walk-behind rotary mower set at a height of $40 \mathrm{~mm}$. Irrigation from June to August was applied once every 2 weeks at $40 \% \mathrm{ET}_{\mathrm{o}}$. Summer annual weed control in 2008 and 2009 was achieved by applying the selective postemergence herbicide fenoxaprop-ethyl in mid-June at label rate.

Turfgrass quality was assessed by means of a visual rating scale recommended by the National Turfgrass Evaluation Program [NTEP (Krans and Morris, 2007)]. Turfgrass quality was determined weekly from Oct. 2007 to Sept. 2009 on a scale of 1 to 9 , with $1=$ dead turf; $9=$ dark green, uniform turf; and $6=$ minimum acceptable quality. The ratings were averaged every three months (January to March, April to June, July to September, and October to December) and analyzed as four different seasons. NDVI were collected weekly from Jan. to Sept. 2009 using a hand-held multispectral radiometer (Greenseeker hand-held optical sensor model 505; NTech Industries, Ukiah, CA) and also averaged over each season.

Seasonal ratings of visual quality, NDVI, and values for green and weed cover at 60 DAS were subjected to an analysis of variance (ANOVA). To test the effects of seeding date and turfgrass cultivars on turfgrass quality and NDVI, data were subjected to a repeated-measures analysis (compound symmetry covariance structure) using Proc mixed of SAS (version 9.2; SAS Institute, Cary, NC). Fisher's protected least significant difference test was used at the 0.05 level of probability to identify significant differences between means.

\section{Results and discussion}

Establishment. The ANOVA of green cover and weed cover revealed significant cultivar and seeding date effects. The interaction between the two main effects was not significant (Table 2). When data were averaged over cultivars, plots seeded in autumn exhibited greater green cover $(80 \%) 60$ DAS than plots seeded in spring $(73 \%)$. Furthermore, plots seeded in the autumn had lower weed coverage $(6 \%)$ than those seeded in spring (16\%). The differences in groundcover between autumn- and springseeded plots may be due to cooler temperatures during the autumn establishment period (Table 1). During the two months after seeding, air and soil temperatures in spring were greater than in autumn. Reicher et al. (2000) also attributed the slow rate of establishment of spring-seeded kentucky bluegrass to high air temperatures after the first months of sowing. The authors also reported that tall fescue establishment was less affected by seeding date than kentucky bluegrass.

When data were pooled over seeding dates, all hybrid bluegrass and kentucky bluegrass cultivars except Geronimo kentucky bluegrass had less coverage than the three tall fescue cultivars (Fig. 1). 'Thermal Blue Blaze' and 'Solar Green' hybrid bluegrass and 'Cocktail' kentucky bluegrass had lowest green coverage 60 DAS. These findings are similar to

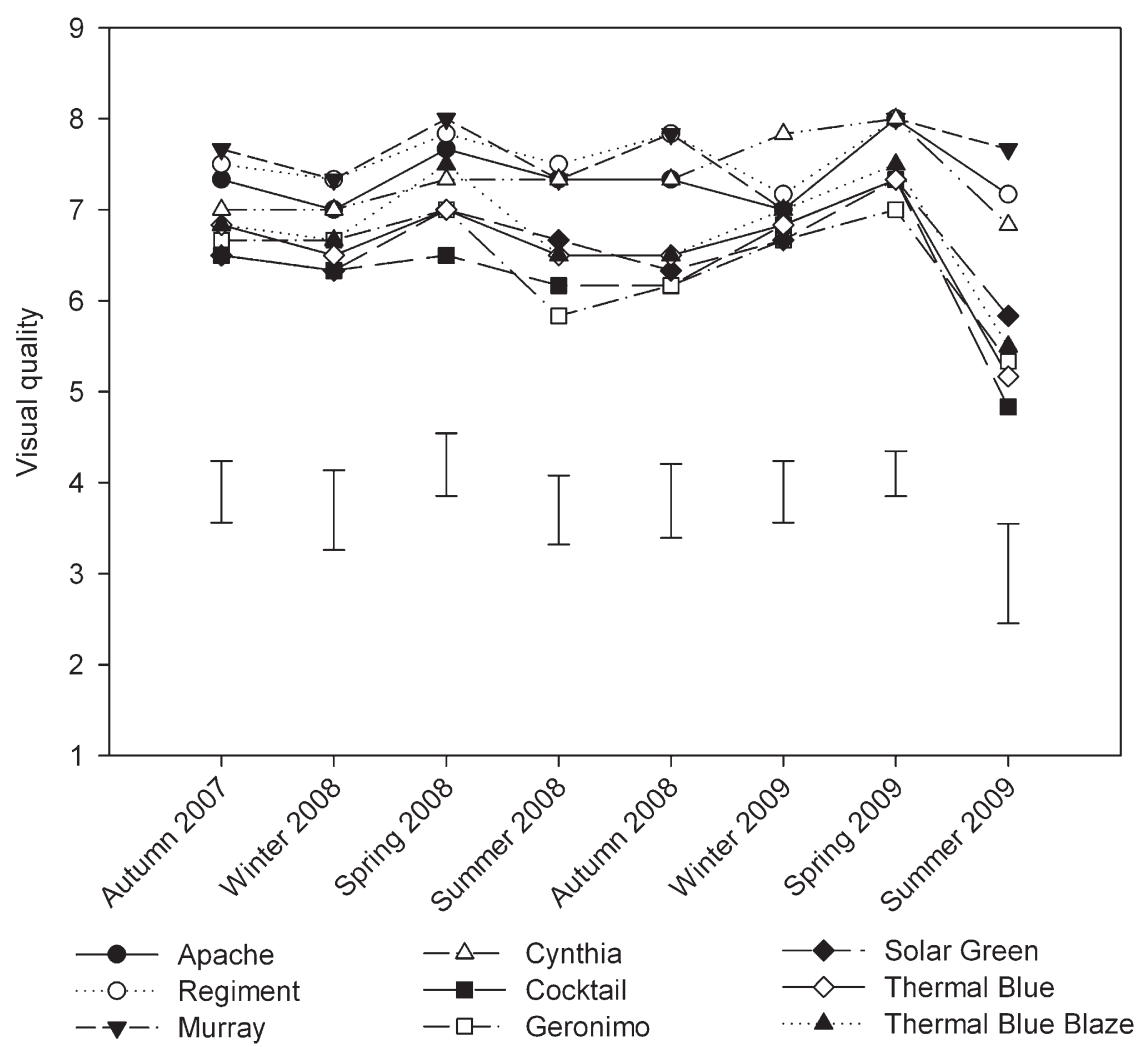

Fig. 2. Visual quality ratings ( 1 = worst, 9 = best) for tall fescue ('Apache', 'Regiment', 'Murray'), kentucky bluegrass ('Cynthia', 'Cocktail', 'Geronimo'), and hybrid bluegrass ('Solar Green', 'Thermal Blue', 'Thermal Blue Blaze') cultivars during Autumn 2007 and 2008; and Winter, Spring, and Summer 2008 and 2009. Data points represent an average of two seeding dates (23 Mar. 2007 and 20 Sept. 2007 ) and three replicates. Vertical bars indicate Fisher's protected least significant difference test at $\boldsymbol{P}=\mathbf{0 . 0 5}$, and can be used to determine significant differences among cultivars within seasons. 
those of Bremer et al. (2006), who reported that tall fescue reached full cover over one month earlier than hybrid bluegrass or kentucky bluegrass. As a result of reduced green coverage, all kentucky bluegrass and hybrid bluegrass had greater weed coverage than the tall fescue cultivars. However, no cultivar differences in weed coverage were observed within each species (Fig. 1).

TURf QUALITY. The analysis of turf quality data revealed significant two-way interactions between sampling date and cultivar, sampling date and seeding date, and cultivar and seeding date (Table 2 ). The seeding date markedly influenced cultivar performance during the entire period of study. Throughout the entire study period, with the exception of Autumn 2007 and Winter 2008, quality was significantly greater in grasses seeded in September than in those seeded in March (Fig. 3). Moreover, with the exception of Summer 2009, turfgrass quality of grasses seeded in the autumn exceeded a rating of 7 on all sampling dates. A significant positive relationship $\left(R^{2}=0.502, P<0.001\right)$ was observed between green cover measured 60 DAS and mean visual quality of the grasses (Fig. 4). This relationship further documents the poorer performance of the springseeded hybrid bluegrass and kentucky bluegrass as a consequence of their slower establishment and suggests that overall appearance of cultivars may be adversely affected by delays in establishment, particularly under reducedinput maintenance.

When quality data were averaged over all sampling dates, seeding date did not affect visual appearance of all tall fescue cultivars or 'Cynthia' and 'Geronimo' kentucky bluegrass (Table 3). Highest quality ratings were observed in plots of tall fescue cultivars Murray, Regiment, and Apache after both spring and autumn seeding. 'Cynthia' was the only kentucky bluegrass that achieved ratings similar to those in tall fescue cultivars tested. Quality of 'Solar Green' and 'Thermal Blue' hybrid bluegrass was inferior to that of all tall fescue cultivars and to 'Cynthia', the best kentucky bluegrass (Table 3 ). Our results concur with those of Baird et al. (2009) and Richardson et al. (2009), who reported that 'Thermal Blue' hybrid bluegrass performed poorly under drought

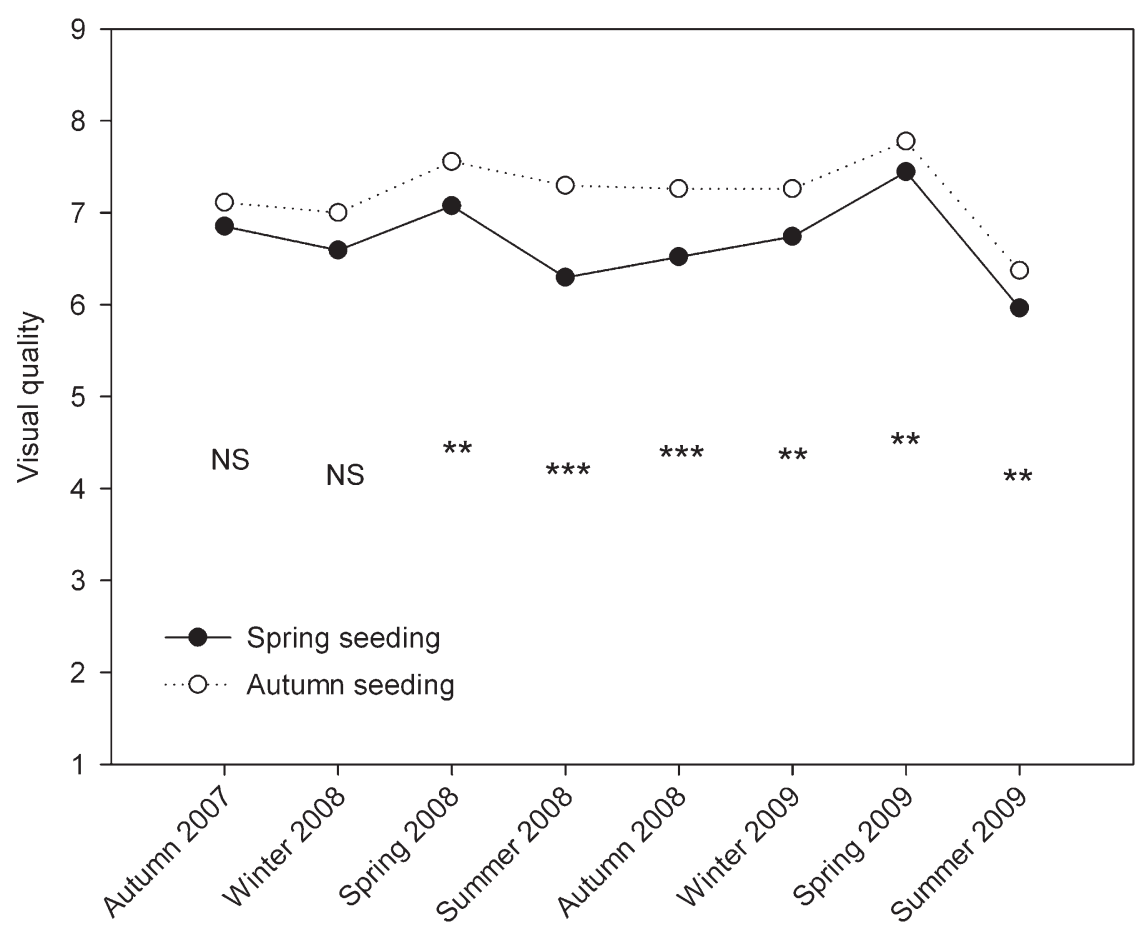

Fig. 3. Visual quality ratings $(1=$ worst, 9 = best) for spring seeding ( 23 Mar. 2007) and autumn seeding (20 Sept. 2007) from Autumn 2007 to Summer 2009. Data points represent an average of nine turfgrass cultivars (Apache, Regiment, and Murray tall fescue; Cynthia, Cocktail, and Geronimo kentucky bluegrass; Solar Green, Thermal Blue, and Thermal Blue Blaze hybrid bluegrass) and three replicates. Statistical differences between spring seeding and autumn seeding are indicated by ${ }^{*}(P \leq 0.01)$ and $* * *(P \leq 0.001), \mathrm{NS}=$ not significant.

stress compared with several kentucky bluegrass cultivars. The three hybrid bluegrass cultivars and 'Cocktail' kentucky bluegrass produced greater quality from autumn seeding than from spring seeding (Table 3 ).

In general, visual quality ratings of hybrid bluegrass and kentucky bluegrass cultivars were lower than those of tall fescue cultivars (Table 3, Fig. 2). Greatest differences between bluegrass and tall fescue were observed during the Summer 2009, compared with Summer 2008. All three tall fescue cultivars maintained high quality even during the warmer months. Our results are similar to those of $\mathrm{Su}$ et al. (2008), who reported a consistently higher visual quality of tall fescue cultivars in comparison with kentucky bluegrass and hybrid bluegrass when grasses were maintained at a water deficit. Jiang and Huang (2001) and Su et al. (2008) documented a greater drought resistance in tall fescue compared with kentucky bluegrass or hybrid bluegrass and attributed it to a deep root system. Among the kentucky bluegrass cultivars tested, Cynthia maintained a similar summer quality

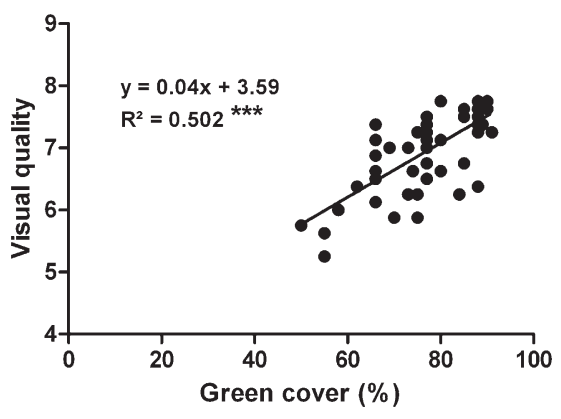

Fig. 4. Relationship between percent green cover at $60 \mathrm{~d}$ after seeding and the mean of visual quality ratings $(1=$ worst, 9 = best) of nine turfgrass cultivars (Apache, Regiment, and Murray tall fescue; Cynthia, Cocktail, and Geronimo kentucky bluegrass; and Solar Green, Thermal Blue, and Thermal Blue Blaze hybrid bluegrass) collected from Autumn 2007 to Summer 2009; *** significant at $P \leq 0.001$.

to that of tall fescue (Fig. 2). Although a superior drought tolerance in 'Cynthia' has not yet been documented, general cultivar differences in turf quality among bluegrasses have been reported by NTEP (2012). 
Table 3. Turf quality ratings for spring-seeded (23 Mar. 2007) and autumnseeded (20 Sept. 2007) tall fescue (TF), kentucky bluegrass (KBG), and hybrid bluegrass $(\mathrm{HBG})$ cultivars. Data are averaged over eight evaluation periods (seasons) from Oct. 2007 to Sept. 2009 and three replicates.

\begin{tabular}{lcc}
\hline & \multicolumn{1}{c}{ Spring seeding } & Autumn seeding \\
\cline { 2 - 3 } Cultivar & $7.3 \mathrm{abc}^{\mathrm{y}}$ & $7.5 \mathrm{ab}$ \\
Apache (TF) & $7.5 \mathrm{ab}$ & $7.6 \mathrm{a}$ \\
Regiment (TF) & $7.6 \mathrm{a}$ & $7.6 \mathrm{a}$ \\
Murray (TF) & $7.2 \mathrm{bc}$ & $7.5 \mathrm{ab}$ \\
Cynthia (KBG) & $5.8 \mathrm{~g}$ & $6.9 \mathrm{~cd}$ \\
Cocktail (KBG) & $6.3 \mathrm{ef}$ & $6.5 \mathrm{de}$ \\
Geronimo (KBG) & $6.1 \mathrm{fg}$ & $7.0 \mathrm{c}$ \\
Solar Green (HBG) & $6.3 \mathrm{ef}$ & $6.9 \mathrm{~cd}$ \\
Thermal Blue (HBG) & $6.3 \mathrm{ef}$ & $7.3 \mathrm{abc}$ \\
Thermal Blue Blaze (HBG) & &
\end{tabular}

${ }^{\mathrm{z}} 1$ = worst, 9 = best.

yeans followed by the same letter do not differ significantly via Fisher's protected least significant difference test at $P \leq 0.05$.

Table 4. Values of normalized difference vegetation index of tall fescue (TF), kentucky bluegrass (KBG), and hybrid bluegrass (HBG) cultivars for Winter, Spring, and Summer 2009. Data are averaged over two seeding dates [spring seeding (23 Mar. 2007) and autumn seeding (20 Sept. 2007)] and three replicates.

\begin{tabular}{lccc}
\hline Cultivar & Winter 2009 & Spring 2009 & Summer 2009 \\
\hline Apache (TF) & $0.85 \mathrm{~A}^{\mathrm{z}} \mathrm{c}^{\mathrm{z}}$ & $0.87 \mathrm{~A} \mathrm{ab}$ & $0.86 \mathrm{~A} \mathrm{a}$ \\
Regiment (TF) & $0.89 \mathrm{~A} \mathrm{ab}$ & $0.88 \mathrm{~A} \mathrm{a}$ & $0.87 \mathrm{~A} \mathrm{a}$ \\
Murray (TF) & $0.86 \mathrm{~A} \mathrm{bc}$ & $0.88 \mathrm{~A} \mathrm{a}$ & $0.86 \mathrm{~A} \mathrm{a}$ \\
Cynthia (KBG) & $0.92 \mathrm{~A} \mathrm{a}$ & $0.87 \mathrm{~A} \mathrm{ab}$ & $0.61 \mathrm{~B} \mathrm{~b}$ \\
Cocktail $(\mathrm{KBG})$ & $0.89 \mathrm{~A} \mathrm{ab}$ & $0.85 \mathrm{~A} \mathrm{bc}$ & $0.50 \mathrm{~B} \mathrm{bc}$ \\
Geronimo (KBG) & $0.87 \mathrm{~A} \mathrm{bc}$ & $0.84 \mathrm{~A} \mathrm{c}$ & $0.52 \mathrm{~B} \mathrm{bc}$ \\
Solar Green $(\mathrm{HBG})$ & $0.89 \mathrm{~A} \mathrm{ab}$ & $0.87 \mathrm{~A} \mathrm{ab}$ & $0.59 \mathrm{~B} \mathrm{bc}$ \\
Thermal Blue (HBG) & $0.88 \mathrm{~A} \mathrm{bc}$ & $0.86 \mathrm{~A} \mathrm{abc}$ & $0.50 \mathrm{~B} \mathrm{c}$ \\
Thermal Blue Blaze (HBG) & $0.89 \mathrm{~A} \mathrm{ab}$ & $0.86 \mathrm{~A} \mathrm{abc}$ & $0.53 \mathrm{~B} \mathrm{bc}$ \\
\hline
\end{tabular}

${ }^{2}$ Values followed by the same letter are not significantly different from one another (Fisher's protected least significant difference test, $P \leq 0.05$ ). Lowercase letters denote differences between cultivars (in columns) and uppercase letters denote differences between seasons for each cultivar separately.

Normalized DIFFERENCE VEGETATION INDEX. The ANOVA revealed a significant effect of the two-way interaction between sampling date and cultivar on NDVI (Table 2). Generally, NDVI values in all grasses remained high during Winter and Spring 2009 (Table 4), but values dropped sharply from Spring to Summer 2009 for kentucky bluegrass and hybrid bluegrass. The decline in NDVI indicated drought stress resulting from the lack of rainfall during this time period (Table 1 ) and corresponded with the decline in turf quality (Fig. 2). In contrast, NDVI values in the tall fescue cultivars tested remained high throughout the investigative period, with summer values as high as those measured in winter and spring (Table 4). Moreover, NDVI values were higher for tall fescue than for kentucky bluegrass or hybrid bluegrass at the end of the investigative period (Fig. 2, Table 4). No consistent significant differences in NDVI were detected between kentucky bluegrass and hybrid bluegrass during 2009 (Table 4).

The 2009 data revealed a significant correlation between NDVI values and turf quality ratings $(r=0.780 ; P<$ $0.001)$. These findings support those of Bremer et al. (2011) who reported a similar relationship in tall fescue and kentucky bluegrass. This significant correlation suggests that NDVI measurements could be useful to objectively estimate turfgrass quality, thus eliminating the subjective nature of visual quality assessments.

Our results indicate that tall fescue performs better than hybrid bluegrass or kentucky bluegrass under drought stress conditions in Mediterranean transition zones regardless of seeding in autumn or spring. Quality of hybrid bluegrass was either similar or lower than that of kentucky bluegrass cultivars. Autumn seeding enhanced the establishment and performance of all bluegrass cultivars. Our data suggest that hybrid bluegrass cannot replace tall fescue under reduced irrigation conditions in a Mediterranean climate. However, these grasses may be used instead of kentucky bluegrass if sown in autumn.

\section{Literature cited}

Abraham, E.M., B. Huang, S.A. Bonos, and W.A. Meyer. 2004. Evaluation of drought resistance for texas bluegrass, kentucky bluegrass, and their hybrids. Crop Sci. 44:1746-1753

Baird, J.H., R.L. Green, S. Mitra, R.V. Plumb, G.J. Klein, and J.R. Frelich. 2009. Response of hybrid bluegrass, kentucky bluegrass and tall fescue to short-term drought recovery in a Mediterranean climate. Intl. Turfgrass Soc. Res. J. 11:1-7.

Beard, J.B. 1973. Turfgrass: Science and culture. Prentice-Hall, Englewood Cliffs, NJ.

Bell, G.E., D.L. Martin, R.M. Kuzmic, M.L. Stone, and J.B. Solie. 2000. Herbicide tolerance of two cold-resistant bermudagrass (Cynodon spp.) cultivars determined by visual assessment and vehicle-mounted optical sensing. Weed Technol. 14:635641.

Bell, G.E., D.L. Martin, S.G. Wiese, D.D. Dobson, M.W. Smith, M.L. Stone, and J.B. Solie. 2002. Vehicle-mounted optical sensing: An objective means for evaluating turf quality. Crop Sci. 42:197-201.

Brede, D. 2000. Turfgrass maintenance reduction handbook: Sports, lawns, and golf. Sleeping Bear Press, Chelsea, MI.

Bremer, D.J., H. Lee, K. Su, and S.J. Keeley. 2011. Relationships between normalized difference vegetation index and visual quality in cool-season turfgrass: I. Variation among species and cultivars. Crop Sci. 51:2212-2218.

Bremer, D.J., K. Su, S.J. Keeley, and J.D. Fry. 2006. Performance in the transition zone of two hybrid bluegrasses compared with kentucky bluegrass and tall fescue. Appl. Turfgrass Sci. doi:10.1094/ATS2006-0808-02-RS.

Bunderson, L.D., P.G. Johnson, K.L. Kopp, and A.V. Dyke. 2009. Tools for evaluating native grasses as low maintenance turf. HortTechnology 19(3):626-632.

Cereti, C.F. 2002. Tappeti erbosi e inerbimenti, p. 335-396. In: R. Baldoni 
and L. Giardini (eds.). Coltivazioni erbacee foraggere e tappeti erbosi. Patron Publishers, Bologna, Italy.

Christians, N.E. 1998. Fundamentals of turfgrass management. 2nd ed. Wiley, Hoboken, NJ.

Croce, P., A. De Luca, M. Falcinelli, F.S. Modestini, and F. Veronesi. 2006. Tappeti erbosi. Edagricole, Bologna, Italy.

Fry, J.D. and B. Huang. 2004. Applied turfgrass science and physiology. Wiley, Hoboken, NJ.

Horst, G.L., M.C. Engelke, and W. Meyers. 1984. Assessment of visual evaluation techniques. Agron. J. 76:619-622.

Huang, B. and J.D. Fry. 1999. Turfgrass evapotranspiration, p. 317-334. In: M.B. Kirkham (ed.). Water use in crop production. Food product press, Binghamton, NY.

Huff, D.R. 2003. Kentucky bluegrass, p. 27-38. In: M.D. Casler and R.R. Duncan (eds.). Turfgrass biology, genetics, and breeding. Wiley, Hoboken, NJ.

Jiang, Y. and B. Huang. 2000. Effects of drought or heat stress alone and in combination on kentucky bluegrass. Crop Sci. 40:1358-1362.

Jiang, Y. and B. Huang. 2001. Physiological responses to heat stress alone or in combination with drought: A comparison between tall fescue and perennial ryegrass. HortScience 36:682-686.

Kenna, M.P. 2008. Turfgrass and the environment, p. 65-90. In: J.B. Beard and M.P. Kenna (eds.). Water quality and quantity issues for turfgrasses in urban landscapes. Printing Services, Belmond, IA.

Krans, J.V. and K. Morris. 2007. Determining a profile of protocols and standards used in the visual field assessment of turfgrasses: A survey of national turfgrass evaluation program-sponsored university scientists. Appl. Turfgrass Sci. doi:10.1094/ ATS-2007-1130-01-TT.

Lee, H., D.J. Bremer, K. Su, and S.J. Keeley. 2011. Relationships between normalized difference vegetation index and visual quality in turfgrasses: Effects of mowing height. Crop Sci. 51:323-332.

Macolino, S., M. Serena, B. Leinauer, and U. Ziliotto. 2010. Preliminary findings on the correlation between water-soluble carbohydrate content in stolons and first year green-up of seeded bermudagrass cultivars. Hort Technology 20:758-763.

Miele, S., M. Volterrani, S. Magni, and K. Gaetani. 2002. Winter quality of tall fescue turf: Effects of renovation technique and nitrogen fertilization. Italian J. Agron. 6(2):97-101.

National Turfgrass Evaluation Program. 2012. 2005 National kentucky bluegrass test-2006-10 data. Final Rpt. NTEP No. 11-10. 10 Sept. 2012. <http://www. ntep.org/reports/kb05/kb05_11-10f/ kb05_1l-10f.htm>.

Read, J.C., J.A. Reinert, P.F. Colbaugh, and W.E. Knoop. 1999. Registration of 'Reveille' hybrid bluegrass. Crop Sci. 39:590.

Read, J.C., D. Walker, and B.W. Hipp. 1994. Potential of texas bluegrass $\times$ kentucky hybrids for turfgrass. Agron. Abstr. p. 183.

Reicher, Z.J., C.S. Throssell, and D.V. Weisenberger. 2000. Date of seeding affects establishment of cool-season turfgrasses. HortScience 35:1166-1169.

Richardson, M.D., D.E. Karcher, K. Hignight, and D.E. Rush. 2008. Drought tolerance and rooting capacity of kentucky bluegrass cultivars. Crop Sci. 48:2429-2436.
Richardson, M.D., D.E. Karcher, K. Hignight, and D. Rush. 2009. Drought tolerance of kentucky bluegrass and hybrid bluegrass cultivars. Appl. Turfgrass Sci. doi:10.1094/ATS-2009-0112-01RS.

Schuerger, A.C., G.A. Capeele, J.A. Di Benedetto, C. Mao, C.N. Thai, M.D. Evans, F.T. Richards, T.A. Blank, and E.C. Stryjewski. 2003. Comparison of two hyperspectral imaging and two laserinduced fluorescence instruments for the detection of zinc stress and chlorophyll concentration in bahiagrass (Paspalum notatum). Remote Sens. Environ. 84: 572-588.

Sheffer, K.M., J.H. Dunn, and D.D. Minner. 1987. Summer drought responses and rooting depth of three cool-season turfgrasses. HortScience 22:296-297.

Su, K., D.J. Bremer, S.J. Keeley, and J.D. Fry. 2007. Effects of high temperature and drought on a hybrid bluegrass compared with kentucky bluegrass and tall fescue. Crop Sci. 47:2152-2161.

Su, K., D.J. Bremer, S.J. Keeley, and J.D. Fry. 2008. Rooting characteristics and canopy responses to drought of turfgrasses, including hybrid bluegrasses. Agron. J. 100:949-956.

Suplick-Ploense, M.R. and Y. Qian. 2005. Evotranspiration, rooting characteristics, and dehydration avoidance: Comparison between hybrid bluegrass and kentucky bluegrass. Intl. Turfgrass Soc. Res. J. 10: 891-898.

Trenholm, L.E., R.N. Carrow, and R.R. Duncan. 1999. Relationship of multispectral radiometry data to qualitative data in turfgrass research. Crop Sci. 39:763-769.

Turgeon, A. 1991. Turfgrass management. Prentice Hall, Englewood Cliffs, NJ. 